21. Sturgeon, P. Studies of iron requirements in infants and children. I. Normal values for serum iron, copper, and free erythrocyte protoporphyrin. Pediatrics, 13: 107 (1954).

22. Weinberg, E. D.: Iron and susceptibility to infectious disease. Science, 384: 952 (1974).

23. Weinberg, E. D.: Roles of iron in host-parasite interactions. J. Infect. Dis., 124: 401 (1971).

Copyright $\odot 1976$ International Pediatric Research Foundation, Inc.
24. Weinberg, E. D.: Systemic salmonellosis: A sequela of sideremia. Texas Rep. Biol. Med., 30: 277 (1972):

25. Hyland Laboratories, Los Aingeles, Calif:

26. Requests for reprints should be addinessed to: H. M. Schulman, Lady Davis Institute for Medical. Reseanch, Jewish General Hospital, 3755 Cote St. Catherine Rd., Montreal', Quebec H3T HEZ (Canada).

27. Accepted for publication September 30, 1975 .

Pediat. Res. 10: 120-126 (1976)

Lymphocytic leukemia mornala phenomenon peripheral blood

\title{
Morula Forms of E Rosettes: Distribution, Specific Inhibition, and Enhancement
}

\author{
SHIH-WEN HUANG, ${ }^{(23)}$ THOMAS BARBER, M. DAVID POULIK, AND RICHARD HONG
}

Departments of Pediatrics and Pathology and the Immunobiology Research Center, University of Wisconsin, Center for Health Sciences, Madison, Wisconsin, and Department of Immunochemistry, Wayne State School of Medicine, Detroit, Michigan, USA

\section{Extract}

Rosette-forming cells ( $R$ FC) with more than 10 sheep red blood cells (SRBC's) per cell defined as morula-forming cells (MFC). were studied in human lymphoid organs and in the peripheral blood (PBL). MFC are most common in the thymus (more than 50\%) and the frequency is much less in peripheral lymphoid tissuesi and in the blood $(29.8 \%$ in those less than 5 years old; $14.9 \%$ in adurts). There is very slight decrease in total RFC in PBL over age 5, but the changes in MFC are quite striking. Treatment with antihuman thymus antiserum (ATS) and with anti-human lymphoblastic antiserum (ATL) resulted in significant inhibition of total rosette and morula rosette formation. No inhibition was seen using normal brain antiserum, anti-IgM antiserum, or anti- $L$ chain antiserum. In two patients with chronic Iymphocytic leukemia and in some cases of thymic deficiency the ratio of MFC to total RFC was unusually high. After culture with phytohemagglutinin (PHA) and conversion to blast forms of after surface peturbation by papain or freeze-thaw treatment, MFC numbers were increased.

\section{Speculation}

The reason that $T$ cells bind SRBC without prior sensitization remains a mystery. Nevertheless, the reaction serves as a reliable detector of a special class of immunologically competent lymphocytes. Subpopulations within the two major classes of human lymphocytes (B and $T$ cells) are now known. We speculate that an analysis of surface markers may help to detect these subclasses. We suggest that the more primitive $T$ cells may show the phenomenon of morula formation. It is postulated that the increase in MFC's might be due to the exposure of hidden sites or alteration of pre-existing surface receptors.

Thymus-derived human peripheral blood lymphocytes are known to form rosettes spontaneously with SR BC $(4-7,11,15,16$, $18,25-27)$. The highest number of RFC are found in thymuses (11,
$15,18,25,27)$; and significantly low RFC have been reported among patients with defective $T$ cell immunity $(4,9,15,21,25,26)$.

In studying human lymphoid cells, we have observed some rosettes with extremely large numbers of surrounding SRBC. If those cells with more than $10 \mathrm{SRBC}$ adherent are enumerated separately, different patterns of distribution in various lymphoid organs as well as in disease states are observed. We have termed the cells which have clusters of many surrounding SRBC the MFC. The number 10 was chosen since 10 SRBC's will usually completely surround a lymphocyte. It was the purpose of this study to further characterize the morula phenomenon by noting distribution patterms in age and disease, by ultrastructural studies, and by observing the effect on monula formation of prior cell treatment with various antisera, PHAS. papain, freezing and thawing, hypotonic treatment, or short term in vitro culture.

\section{MATERIALS AND METHODS}

\section{FOR'MATION OF ROSETTES}

The method was essentially that of Jondal et al. (15) with minor modifications. Peripheral blood mononuclear leukocytes were isolated from heparinized venous blood by Ficoll-Hypaque gradient centrifugation. Lymphocytes from tonsils, lymph nodes, livers, spleens, and thymuses were prepared'by. gentle teasing of fresh tissues and suspension in minimum essential' medium (MEM) (29) with Hank's salts. The source of lymphoid tissue was fetal (30) or surgical specimens; all specimens were normal histologically. Rosettes were prepared by adding: $0.2 \mathrm{ml}$ leukocyte suspension in $\operatorname{MEM}\left(4 \times 10^{8} / \mathrm{ml}\right)$ to $0.25 \mathrm{ml}$ of $0.5 \%$ SR BC in MEM. Cells were mixed thoroughly and incubated at $37^{\circ}$ for $5 \mathrm{~min}$. The mixture was then centrifuged at $200 \times g$ for $5 \mathrm{~min}$ at room temperature and incubated at $4^{\circ}$ for $1-2 \mathrm{hr}$. The cell pellet was resuspended very gently by rocking the tubes. Ten microliters of $0.1 \%$ eosin dye were added to the final cell suspension. At least 200 lymphocytes were counted in a hemocytometer and all lymphocytes binding more than three SR BC were considered to be rosettes. The rosettes were further classified as low binding if less than $10 \mathrm{SRBC}$ adhered to a 
lymphocyte, and high binding or morula (MFC) if more than 10 SRBC clustered around a single lymphocyte.

\section{SURFACE IMMUNOGLOBULIN STAINING}

Mixed with $0.1 \mathrm{ml}$ fluorescein conjugated heavy or light chain antisera (1) and incubated at $4^{\circ}$ for $30 \mathrm{~min}$ were $1-2 \times 10^{6}$ cells/ $0.1 \mathrm{ml}$ MEM. All antisera were spun at $1,500 \times g$ just before use. After three washes in cold MEM cells were examined by fluorescence micrescopy.

\section{BLOCKING OF ROSETTE FORMATION WITH ANTISERA}

Antisera studies included ariti- $\mathrm{B}_{2}$-microglobulin, anti-human brain $(12,31)$, anti-human thymocyte (32), anti-IgM, anti-human L-chain, and antilymphoblast antisera. All antisera had been previously heat-inactivated and exhaustively absorbed with equal volumes of packed SRBC until no agglutination was demonstrable. Antisera $(0.1 \mathrm{mil})$ was incubated with $0.1 \mathrm{ml}$ lymphocyte suspension $\left(4 \times 10^{6} / \mathrm{ml}\right)$ for $11 \mathrm{hr}$. The cells were then washed three times with MEM before being mixed with SRBC for rosette formation in the usual way. Viability was determined by eosin dye exclusion.

\section{EFFECTS OF IN VITRO TREATMENTS ON ROSETTE FORMATION}

Blast cells after PHA stimulation: PBL were stimulated with PHA for $72 \mathrm{hr}$. The cells were collected and rosette iformations of blast cells were estimated. These results were compared with rosette formation by unstimulated cells cultured simultaneously with PHA.

Hypotonic Treatment and Freezing of PBL. To $0.5 \mathrm{ml}$ whole blood were added $9 \mathrm{ml}$ distilled water. Within $30 \mathrm{sec} 1 \mathrm{ml} 10$ times phosphate-buffered saline (PBS) was added and the sample mixed thoroughly. Leukocytes recovered from the cell pellet after centrifugation were tested for rosette formation.

Frozen cells prepared by freezing in 10\% dimethylsulfoxide, were thawed carefully at $37^{\circ}$, washed in MEM three times, and then tested for rosette formation.
Papain Treatment. PBL were treated with papain $(0.06 \mathrm{mg} / \mathrm{ml})$ and cysteine $(2.5 \mathrm{mM})$ in MEM containing $5 \%$ normal human serum as described previously by Chapel (6). After incubation at $37^{\circ}$ for $1 \mathrm{hr}$, cells were washed and resuspended for rosette formation.

\section{CAP FORMATION OF ROSETTE-FORMING CELLS}

After the estimation of rosette formation on PBL, cells were subsequently incubated at $37^{\circ}$ without agitation. The cells were then removed 1,2 , and $4 \mathrm{hr}$ later to study the redistribution of SRBC on the surface of lymphocytes.

TISSUE PREPARATIONS FOR SCANNING (SEM) AND TRANSMISSION ELECTRON MICROSCOPY (TEM)

$T E M$. Suspensions of rosette and cap forming cells were initially fixed in $1 \%$ glutaraldehyde in 0.1 M Soronson's phosphate buffer. Secondary fixation was in $1 \% \mathrm{OsO}$, in $0.1 \mathrm{M} \mathrm{S}$-collidine followed by rinsing in acetate-barbital buffer. After exposure to traditional resin mixtures, cells were placed in full strength catalyzed Epon 812 in conical-tipped polyethylene capsules and centrifuged. The resin was then placed in a $60^{\circ}$ oven for $48 \mathrm{hr}$ to allow polymerization. Ultrathin sections of selected cells were cut on a LK B 8800 Ultratome III, stained with lead citrate and uranyl acetate, and observed in a Philips EM-300 electron microscope with a $30-\mu \mathrm{m}$ objective aperture at $60 \mathrm{KV}$.

$S E M$. A drop of unfixed cells in Hank's balanced salt solution was allowed to adhere to acid-cleaned circular glass covers at $4^{\circ}$ for $15 \mathrm{~min}$. Cells were then fixed in $1 \%$ phosphate-buffered glutaraldehyde with an osmolarity sufficient to cause distension of SRBC in an effort to observe the site of cell attachment. After washing with $0.1 \mathrm{M}$ phosphate-buffer, cells were dehydrated in alcohol and dried using amyl acetate as an intermediate solvent according to the method of Anderson (2). Cells were coated with $200 \AA$ gold-palladium by vacuum evaporation and observed at 25 $\mathrm{KV}$ in a JEOL JSM-U 3 scanning electron microscope.

Table 1. Percentage and total number of rosette-forming zells $(R F C)$ and morula-forming cells $(M F C)$

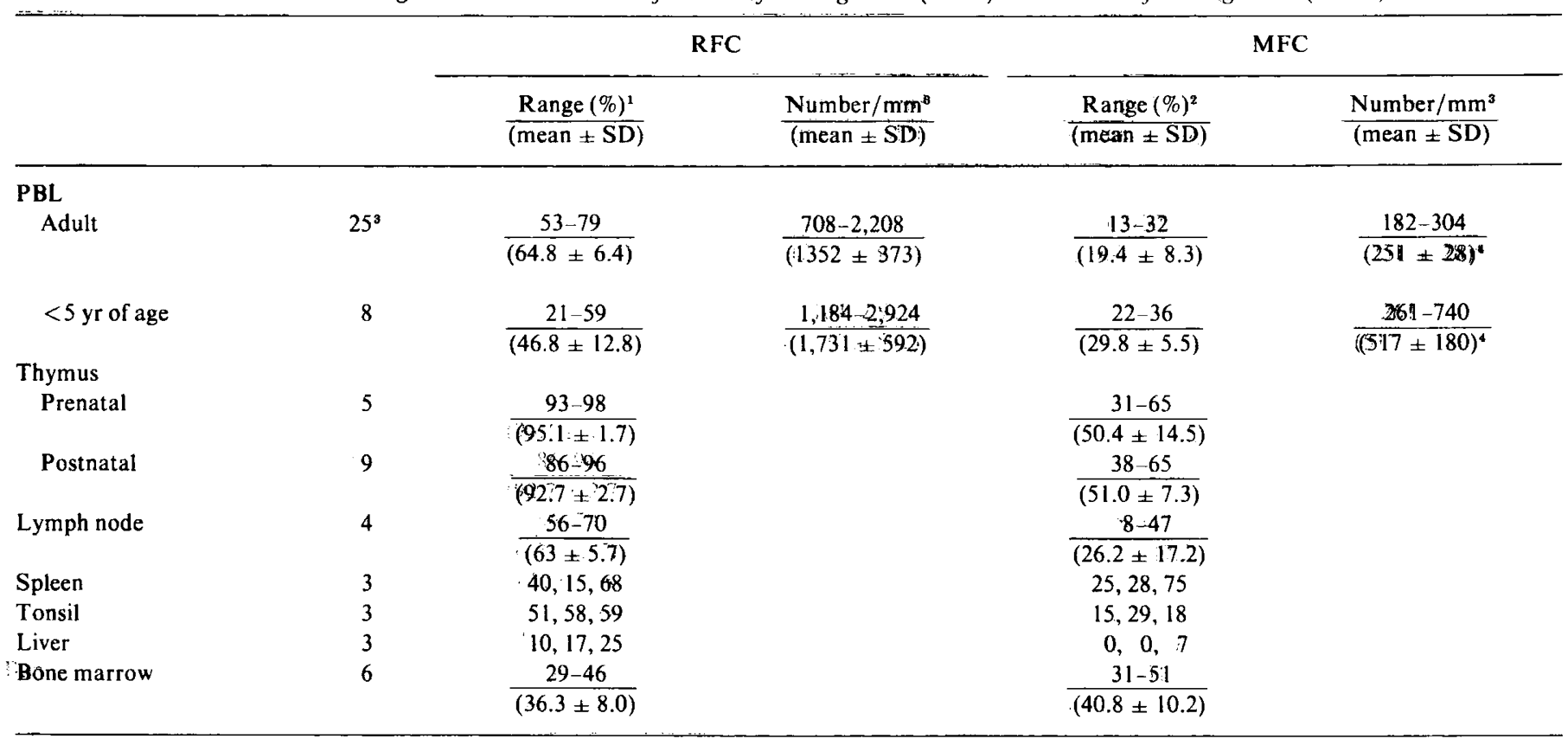

\footnotetext{
${ }^{2}$ Percentage of RFC in cell population.

${ }^{2}$ Percentage of RFC classified as MFC.

${ }^{3}$ Number of samples tested.

${ }^{4}$ Difference between these means significant $(P<0.05)$.
} 


\section{RESULTS}

\section{DISTRIBUTION AND FREQUENCY OF ROSETTE-FORMING CELLS}

The numbers of RFC and MFC in lymphoid organs and PBL are listed in Table 1. The major differences noted are that the number of MFC in the peripheral blood decreases after 5 years of age. Tissue distribution cannot be fully assessed because of sample size, but in the four lymph node samples tested, total and mean MFC counts were about one-half those of five other lymphoid organs examined. Table 2 illustrates the changes in percentage and numbers of peripheral blood RFC and of MFC in those 5 years of age or less. At age 5, the means of samples tested approached the adult mean.

Table 3 shows the distribution of RFC and MFC in a number of immunodeficient states. In patients with chronic lymphatic leukemia the total number of lymphocytes is markedly increased. As reported previously by others, most of these lymphocytes are B lymphocytes; we found from $57-80 \%$ of the lymphocytes were surface immunoglobulin-bearing cells. However, additionally, we

Table 2. Percentage and total number of rosette-forming cells $(R F C)$ and morula-forming cells $(M F C)$ in peripheral blood (donors 5 years of age or less)

\begin{tabular}{lcccc}
\hline \multicolumn{1}{c}{ Age } & $\%^{1}$ & No. $/ \mathrm{mm}^{3}$ & $\%^{2}$ & No. $/ \mathrm{mm}^{3}$ \\
\hline $15 \mathrm{wk}^{3}$ & 21 & 1,750 & 36 & 630 \\
$25 \mathrm{wk}^{3}$ & 35 & 1,714 & 36 & 617 \\
$3 \mathrm{mo}$ & 46 & 2,242 & 33 & 740 \\
$7 \mathrm{mo}$ & 53 & 2,924 & 24 & 702 \\
$1.5 \mathrm{yr}$ & 53 & 1,376 & 30 & 412 \\
$3 \mathrm{yr}$ & 59 & 1,423 & 33 & 470 \\
$5 \mathrm{yr}$ & 54 & 1,236 & 22 & 272 \\
$5 \mathrm{yr}$ & 54 & 1,184 & 25 & 296 \\
& & & & \\
Mean \pm SD & $1731 \pm 592$ & \multicolumn{2}{c}{$517 \pm 180$}
\end{tabular}

${ }^{1}$ Percentage of RFC in cell population.

${ }^{2}$ Percentage of RFC classified as MFC.

${ }^{3}$ Gestational age. noted that two of the patients showed a disproportionate increase of MFC $(K K$ and $H W)$, both relatively and absolutely. Conversely, among patients with combined immunodeficiency, not only was there the expected decrease in total lymphocytes of those lymphocytes present, there were only about one-half the expected number of MFC's. Finally, in two patients with primarily T cell deficiency $(R R$ and $V H)$, there was a striking increase in the proportion of MFC. Absolute and percentage increases of MFC were noted in common variable deficiency $(D G)$ and cyclic neutropenia $(D S)$.

\section{INHIBITION OF ROSETTE FORMATION BY ANTISERA}

Table 4 illustrates changes in rosette formation after PBL were treated in vitro with various antisera. Normal human and goat sera were used as controls. Only treatment with ATS and ALS caused significant reduction of RFC. The heat-inactivated antisera were not cytotoxic to normal PBL as judged by eosin dye exclusion.

\section{OBSERVATION OF EFFECT OF ENHANCEMENT ON MORULA FOR- MATION AFTER IN VITRO TREATMENT}

Hypotonic treatment and short term culture did not change the total numbers of RFC, but increased the number of morula forms significantly as compared with unt reated cells (Table 5). As judged by dye exclusion, there was no deleterious effect on PBL after such treatment. Many blast cells had nearly 100 surrounding SRBC (Fig. 1), and it was clear that some SRBC were not attached to lymphocytes directly; rather they formed a series of layers (Fig. Ia and $2 a$ ). Treatment with papain, phytohemagglutinin, and freezethaw procedures increased both the numbers of RFC and the relative percentage of $\mathrm{MFC}$.

\section{CAP FORMATION OF MFC}

Figures $1 b$ and $2 b$ illustrate the shifting of SRBC to a polar distribution; in Figure 3 the SRBC seem to be detaching continously from the polar area. An interesting observation by TEM was that of the apparent relation of the cell's Golgi apparatus position to the polar areas of cell were "caps" formed (Fig. 3 and 4). Table 6 shows the sequence or events in six separate samples

Table 3. Rosette-forming cells $(R F C)$ and morula-forming cells $(M F C)$ in peripheral blood of immunodeficient patients ${ }^{1}$

\begin{tabular}{|c|c|c|c|c|c|c|c|c|c|c|c|}
\hline \multirow[b]{2}{*}{ Case } & \multirow[b]{2}{*}{ Age, yr } & \multirow[b]{2}{*}{ Diagnosis } & \multicolumn{3}{|c|}{ Lymphocytes } & \multicolumn{2}{|r|}{ RFC } & \multicolumn{2}{|r|}{ MFC } & \multicolumn{2}{|c|}{ B cells $(\%)$} \\
\hline & & & $\begin{array}{l}\text { Total } \\
\text { WBC }\end{array}$ & $\%$ & No. $/ \mathrm{mm}^{3}$ & $\%$ & No. $/ \mathrm{mm}^{3}$ & $\%$ & No. $/ \mathrm{mm}^{3}$ & $\mathrm{Ig}+$ & EAC \\
\hline$D W$ & 35 & CLL & 36,300 & 97 & 35,211 & 5 & 1,761 & 35 & 616 & 80 & \\
\hline$V G$ & 42 & CLL & 18,700 & 79 & 14,773 & 8 & 1,182 & 30 & 355 & 66 & \\
\hline$T S$ & 50 & CLL & 14,900 & 84 & 12,516 & 10 & 1,252 & 27 & 338 & 65 & 8.5 \\
\hline$K K$ & 52 & CLL & 71,200 & 80 & 56,960 & 11 & 6,265 & 50 & 3,133 & 57 & 21 \\
\hline$H W$ & 54 & CLL & 35,200 & 75 & 26,400 & 13 & 3,432 & 45 & 1,544 & 73 & 37 \\
\hline$A W$ & 57 & CLL & 18,500 & 76 & 14,060 & 10 & 1,406 & 30 & 422 & 60 & \\
\hline$D C$ & 2 & SCID & 3,500 & 32 & 1,120 & 31 & 347 & 16 & 56 & 16 & 16 \\
\hline$A K$ & 3 & SCID & 1,700 & 11 & 187 & 32 & 60 & 15 & 9 & 8 & 3 \\
\hline$T B$ & 2 & SCID & 4,200 & 30 & 1,260 & 7 & 88 & 11 & 10 & 15 & 10 \\
\hline$R R$ & 19 & Chronic mucocutaneous candidiasis & 2,500 & 10 & 250 & 22 & 55 & 58 & 32 & 25 & 22 \\
\hline$V H$ & 4 & Cartilage hair hypoplasia ${ }^{2}$ & 6,400 & 30 & 1,920 & 14 & 269 & 36 & 97 & 20 & 8 \\
\hline$D G$ & 9 & Hypogamma, common variable & 7,000 & 47 & 3,290 & 44 & 1,448 & 35 & 507 & 46 & 24 \\
\hline$D S$ & 12 & Cyclic neutropenia & 4,500 & 60 & 2,700 & 75 & 2,025 & 36 & 729 & 28 & 12 \\
\hline$K K$ & 28 & Sarcoid, inactive & 5,500 & 20 & 1,100 & 70 & 770 & 20 & 154 & 18 & 15 \\
\hline$J F$ & 11 & Selective IgA deficiency & 7,300 & 30 & 2,190 & 50 & 1,095 & 15 & 164 & 30 & 25 \\
\hline$S A$ & 13 & Selective IgA deficiency & 6,730 & 35 & 2,356 & 48 & 1,131 & 18 & 204 & 22 & 10 \\
\hline$D A$ & 12 & Selective IgA deficiency & 3,960 & 52 & 2,059 & 60 & 1,236 & 25 & 309 & 15 & 8 \\
\hline
\end{tabular}

${ }^{1}$ CLL: chronic lymphocytic leukemia; SCID: severe combined immunodeficiency.

${ }^{2}$ Isolated T cell deficiency. 
Table 4. Rosette inhibition tests ${ }^{1}$

\begin{tabular}{|c|c|c|c|c|c|c|c|c|c|c|}
\hline \multirow[b]{3}{*}{ Antisera } & \multicolumn{10}{|c|}{ Specimen no. } \\
\hline & \multicolumn{2}{|c|}{1} & \multicolumn{2}{|c|}{2} & \multicolumn{2}{|c|}{4} & \multicolumn{2}{|c|}{4} & \multicolumn{2}{|c|}{5} \\
\hline & $\mathbf{R}^{2}$ & $\mathrm{M}^{3}$ & $\mathrm{R}$ & $\mathbf{M}$ & $\mathbf{R}$ & $\mathbf{M}$ & $\mathbf{R}$ & $\mathbf{M}$ & $\mathbf{R}$ & $\mathbf{M}$ \\
\hline No serum & 60 & 20 & 64 & 25 & 61 & 18 & 67 & 21 & 61 & 23 \\
\hline Normal goat serum & 68 & 23 & 69 & 27 & 68 & 26 & 66 & 30 & 63 & 17 \\
\hline Normal human serum & 51 & 18 & 64 & 22 & 57 & 20 & 60 & 24 & 67 & 19 \\
\hline Anti- $\beta_{2}-$ microglobulin ${ }^{4}$ & 58 & 20 & 43 & 23 & 53 & 16 & 54 & 19 & 58 & 18 \\
\hline Anti-brain $\mathrm{Ab}^{4}$ & 54 & 24 & 65 & 26 & 53 & 19 & 60 & 20 & 58 & 20 \\
\hline Anti-IgM & 68 & 22 & 71 & 20 & 60 & 21 & 63 & 19 & 65 & 19 \\
\hline Anit-L-chain & 63 & 19 & 62 & 22 & 62 & 20 & 58 & 23 & 61 & 21 \\
\hline Antilymphoblast antiserum & 33 & 0.5 & 38 & 0.3 & 35 & 5 & 37 & 0.2 & 30 & 2 \\
\hline Antithymocyte antiserum ${ }^{4}$ & 0.9 & 0.0 & 0.7 & 0.0 & 3 & 0.0 & 0.3 & 0.0 & 2 & 0.0 \\
\hline
\end{tabular}

${ }^{1}$ At least 300 lymphocytes were counted for each experiment. All tests were performed simultanelusly.

${ }^{2}$ Percentage of rosette-forming cells in cell population.

${ }^{3}$ Percentage of rosette-forming cells classified as morula-forming cells.

${ }^{4}$ See text.

Table 5. Change of rosette-forming cells $(R F C)$ and morula form after in vitro physical or chemical treatment of peripheral blood from normal subjects

\begin{tabular}{|c|c|c|c|c|c|c|c|c|c|c|c|c|}
\hline & \multicolumn{12}{|c|}{ Specimen no. } \\
\hline & \multicolumn{2}{|c|}{1} & \multicolumn{2}{|c|}{2} & \multicolumn{2}{|c|}{3} & \multicolumn{2}{|c|}{4} & \multicolumn{2}{|c|}{5} & \multicolumn{2}{|c|}{6} \\
\hline & $\mathbf{R}^{\mathbf{a}}$ & $\mathbf{M}^{\mathbf{b}}$ & $\mathbf{R}$ & $\mathbf{M}$ & $\mathbf{R}$ & $\mathbf{M}$ & $\mathrm{R}$ & $\mathbf{M}$ & $\mathrm{R}$ & $\mathbf{M}$ & $\mathrm{R}$ & $\mathbf{M}$ \\
\hline No treatment & 69 & 14 & 62 & 13 & 56 & 17 & 54 & 12 & 56 & 11 & 69 & 30 \\
\hline Hypotonic treatment & 64 & 34 & 73 & 50 & 76 & 36 & 71 & 37 & 61 & 50 & 66 & 55 \\
\hline 3 days' culture & 60 & 28 & 53 & 31 & 63 & 13 & 66 & 21 & 60 & 24 & 74 & 41 \\
\hline $\begin{array}{l}\text { Phytohemagglutinin and } 3 \text { days' } \\
\text { culture }^{3}\end{array}$ & 81 & 60 & 70 & 59 & 87 & 74 & 88 & 62 & 89 & 83 & 93 & 78 \\
\hline Papain treatment & 91 & .77 & 96 & 78 & 86 & 90 & 86 & 40 & 83 & 41 & 84 & 58 \\
\hline Frozen and thawed & 86 & 58 & 88 & 62 & 86 & 29 & 82 & 33 & 83 & 39 & 76 & 41 \\
\hline
\end{tabular}

${ }^{1}$ Percentage of RFC in cell population.

${ }^{2}$ Percentage of RFC classified as morula-forming cells.

${ }^{3}$ Only blast cells were counted.
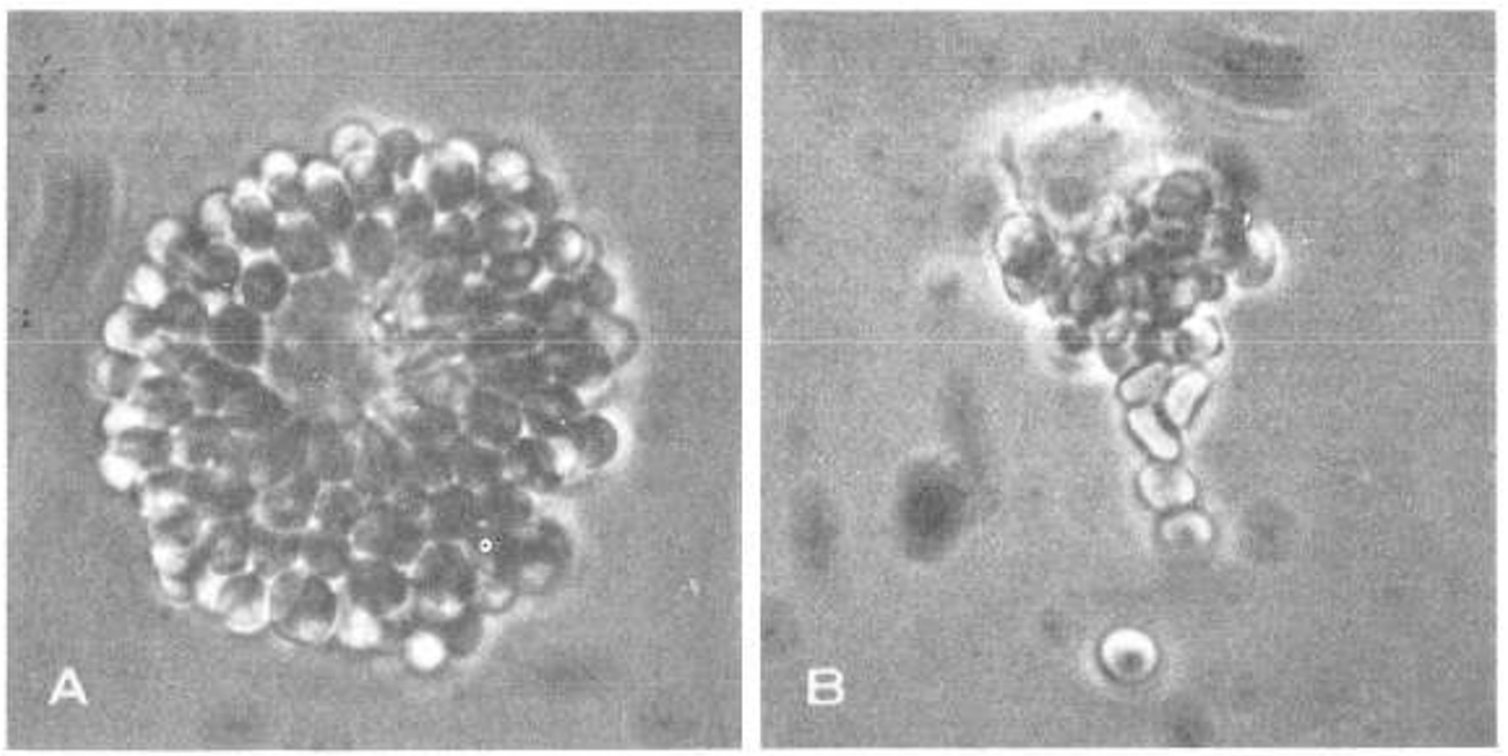

Fig. 1. A: norula form of sheep cell rosette seen after 3-day incubation of normal human lymphocytes with phytohemagglutinin (original magnification $\times 400)$; $B$ : shifting of erythrocytes to polar distribution with beginning detachment $(\times 400)$. 
which were studied. At zero time, i.e., when the fully formed rosettes were first examined, all SRBC are either arranged as complete multilayer structures (morulas) or with less than 10 peripheral SR BC all touching the central lymphocyte. With time, a "capping" phenomenon occurs where multilayering is seen, but not occupying the entire circumference. The percentage of both MFC and RFC types of rosettes observed in this form is recorded in Table 6. Approximately one-third of the rosettes show capping at $2 \mathrm{hr}$ and $80 \%$ at $4 \mathrm{hr}$.

\section{MORPHOLOGY OF RFC BY TEM AND SEM}

Thymic-derived lymphocytes observed during the course of study were characteristically of a $9-15 \mu \mathrm{m}$ diameter with low to moderate numbers of surface microvilli and invaginations, a reniform nucleus with condensed chromatin, moderate numbers of mitochondria and polysomal particles, scant endoplasmic reticulum, and often fairly well-developed Golgi profiles (Fig. 4). Red cells were occasionally seen adhering to lymphocytes by microspikes or elongated cell processes. Occasionally, zones of intercellular contact were seen to be made up of discontinuous electron-dense areas "bridges" between cells instead of a uniform electron-dense band (Fig. 4).

\section{DISCUSSION}

For normal adults our study revealed a range of $64.8 \pm 6.8 \%$ RFC (Table 1) which is in agreement with the work of others $(4,6$, $15,21)$. The discrepancy between our data and those of some others $(18,25)$ is probably due to different techniques employed involving differences in cell concentrations and conditions of incubation. After age 5 there may be some slight diminution of total RFC but statistically significant changes are seen only in MFC which are approximately $50 \%$ less in other individuals.

Observations of lymphoid tissue showed that more than one half of thymocytes were MFC; the distribution was the same in prenatal or postnatal specimens (Table 1). In other organs, distribution of total RFC and MFC varied but the portion of RFC which are morulas is less than within the thymus.

Rosette formation could be inhibited almost completely by ATS while inhibition by ALS was $50 \%$; however, there were virtually no morula form rosettes visible after ALS treatment. Inhibition of RFC by ALS was also reported by Brain et al. (5) and Wortis et al. (28). Coombs et al. (7) and Jondal et al. (15) have shown that anti-immunoglobulin antisera would not inhibit rosette formation. Our studies using anti-human IgM or anti L-chain antiserum are in agreement with theirs but contrary to the observation of Wybran et al. (25). The reason for this discrepancy is not clear. The inability of antibrain or anti- $\beta_{2}$-microglobulin antisera to inhibit rosette formation is of interest. The antisera were capable of coating appropriate lymphocytes for, by indirect fluorescent techniques, all $\mathrm{T}$ cells were shown to be coated by the antibrain antiserum. Furthermore, $\boldsymbol{\beta}_{2}$-microglobulin has been observed on all lymphoid cells (19), although a previous study (10) has suggested this surface receptor is restricted to $T$ cells. The failure to inhibit SR BC binding by these antisera as contrasted to antilymphoblast or antithymocyte antibodies is of interest in view of the demonstration that antiserum to $\boldsymbol{\beta}_{\mathbf{2}}$-microglobulin has profound inhibitory effects on in vitro lymphocyte stimulation by PHA, allogeneic cells, and antigen despite its lack of effect upon formation of rosettes (3). The disparity suggests that the rosette forming site is located far from sites important in initiating in vitro proliferation. The $\beta_{2}$ site and the rosette forming site may have markedly different densities which account for the disparate antibody response. None of the antiserum used were cytotoxic as defined by eosin dye exclusion capability.

As shown by others, immunodeficient cases who had primary $T$ cell defects showed low percentages of RFC (Table 3) $(21,25,26)$. However, an increase of the MFC/RFC ratio was seen in cases $R R$ and $V H$. Absolute increases, as well, were seen in nonlymphopenic host defense abnormalities: one patient with common variable immunodeficiency and one with cyclic neutropenia. Two patients with chronic lymphocytic leukemia showed $50 \%$ and $45 \%$ MFC, respectively, indicating a disproportionate number of the morula form. No normal adult studied by us had more than $32 \%$ MFC's. An increase in the ratio of MFC/RFC was also observed in a case of common variable immunodeficiency. Thus, variations in total numbers of RFC's do not always show parallel and proportionate changes in morulas. It might be that morula forms denote a subpopulation of $\mathrm{T}$ cells. The higher proportion among nonperipheralized thymic cells, among "blast" cells produced by PHA stimulation and in younger individuals suggests that perhaps the morula form is a less mature rosette cell. If so, its increase in deficiency states might represent a state of maturation arrest.

Concomitant TEM and SEM studies confirmed that rosettes were almost exclusively formed by lymphocytes. Our results are consistent with the findings of others $(13,17)$, who showed that binding sites in rosettes vary in size from small pointlike areas to broader zone contact.

The morphology of the MFC is quite unique as compared with the other forms of the RFC's. The fact that no direct contact of red cells in the outer layers with the central lymphocyte was observed
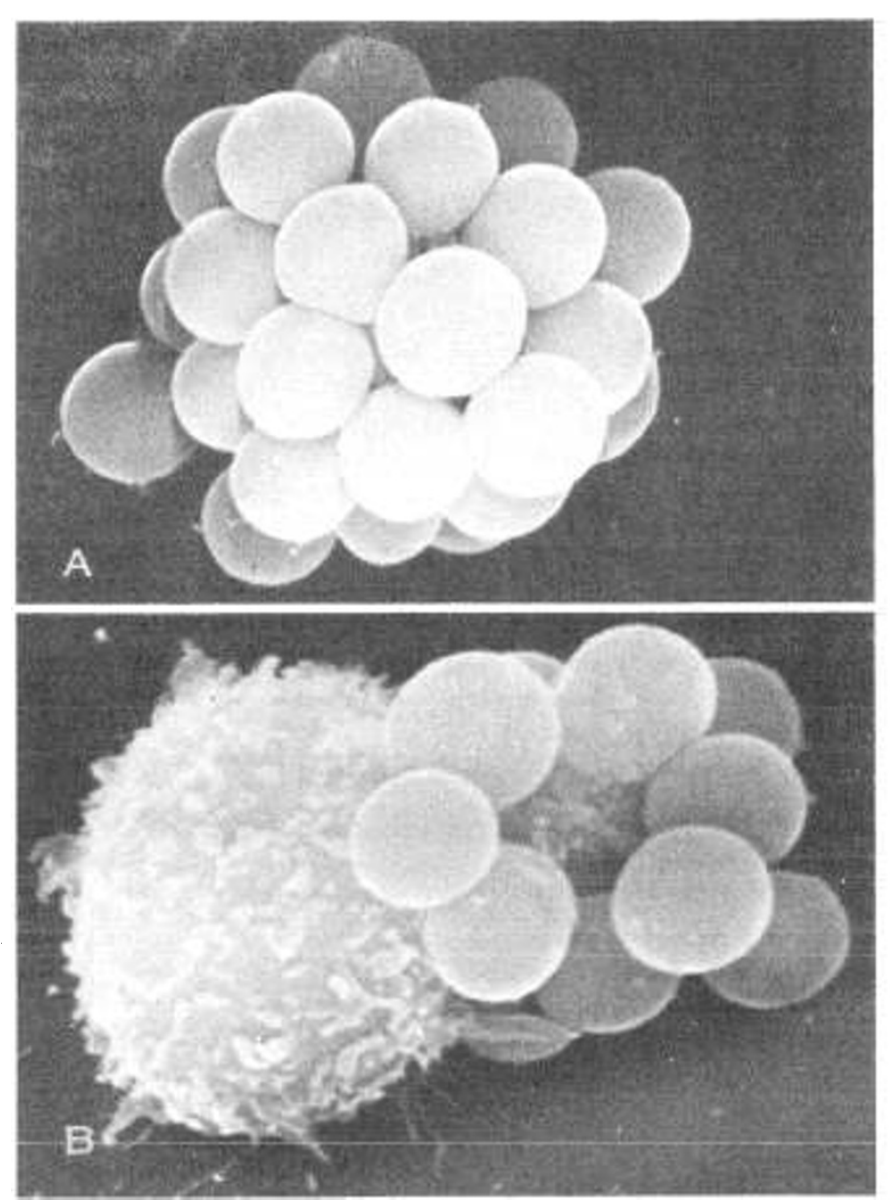

Fig. 2. $A$ : scanning electron micrograph of morula $(\times 12,350) ; B$ : scanning electron micrograph of "capped" rosette-forming cell $(\times 17,800)$.

Table 6. Percentage of capping at various times

\begin{tabular}{ccccc}
\hline No. & $0 \mathrm{hr}$ & $\mathrm{I} \mathrm{hr}$ & $2 \mathrm{hr}$ & $4 \mathrm{hr}$ \\
\hline 1 & 0 & 10 & 30 & 80 \\
2 & 0 & 8 & 35 & 75 \\
3 & 0 & 5 & 33 & 75 \\
4 & 0 & 20 & 38 & 80 \\
5 & 0 & 15 & 35 & 75 \\
6 & 0 & 25 & 40 & 80 \\
\hline
\end{tabular}




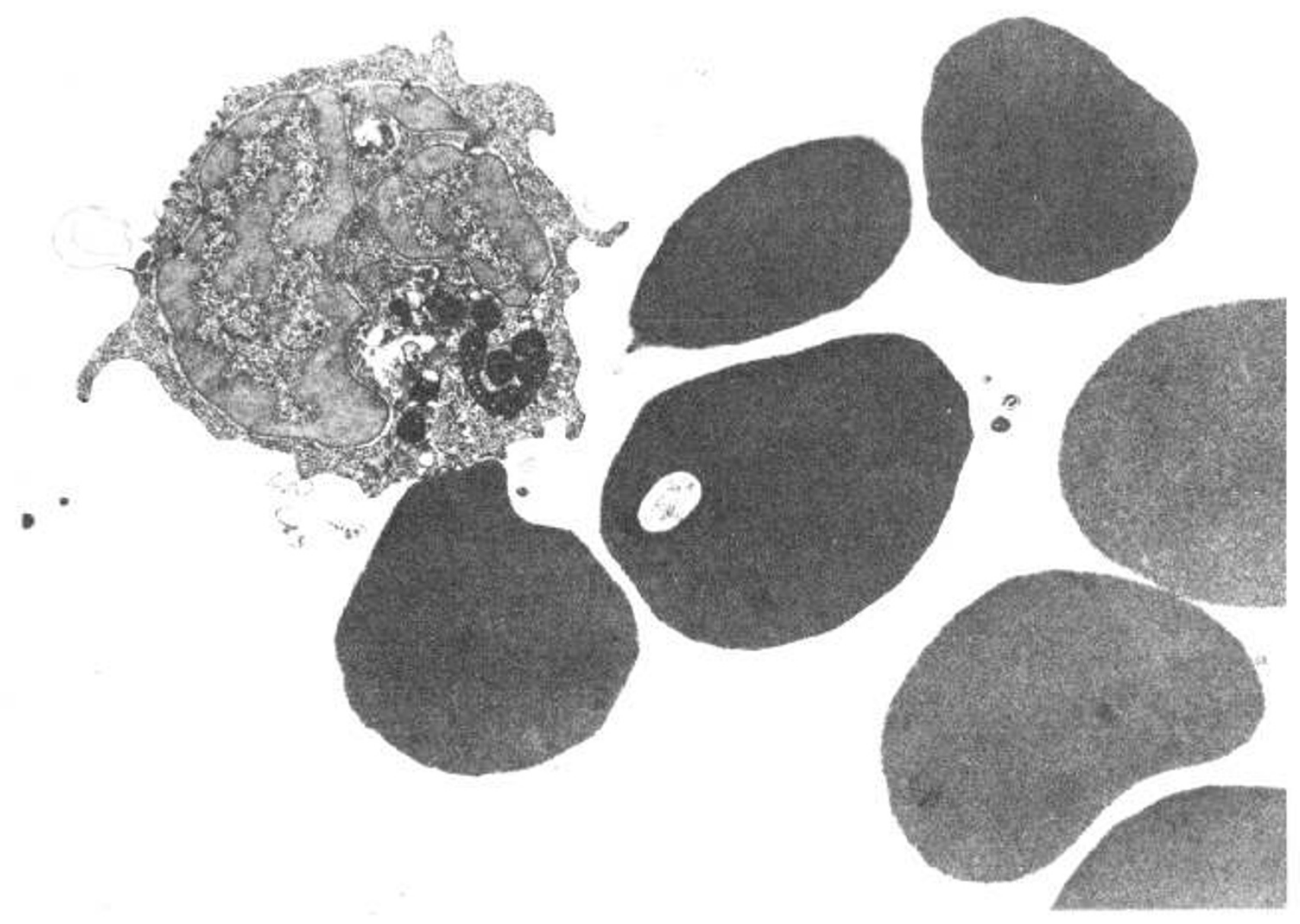

Fig. 3. Capped rosette-forming cell. Intracytoplasmic vesicles of the lymphorvte are visible at the point of attachment of an erythrocyte $(\times 11,650)$. Lead stain.

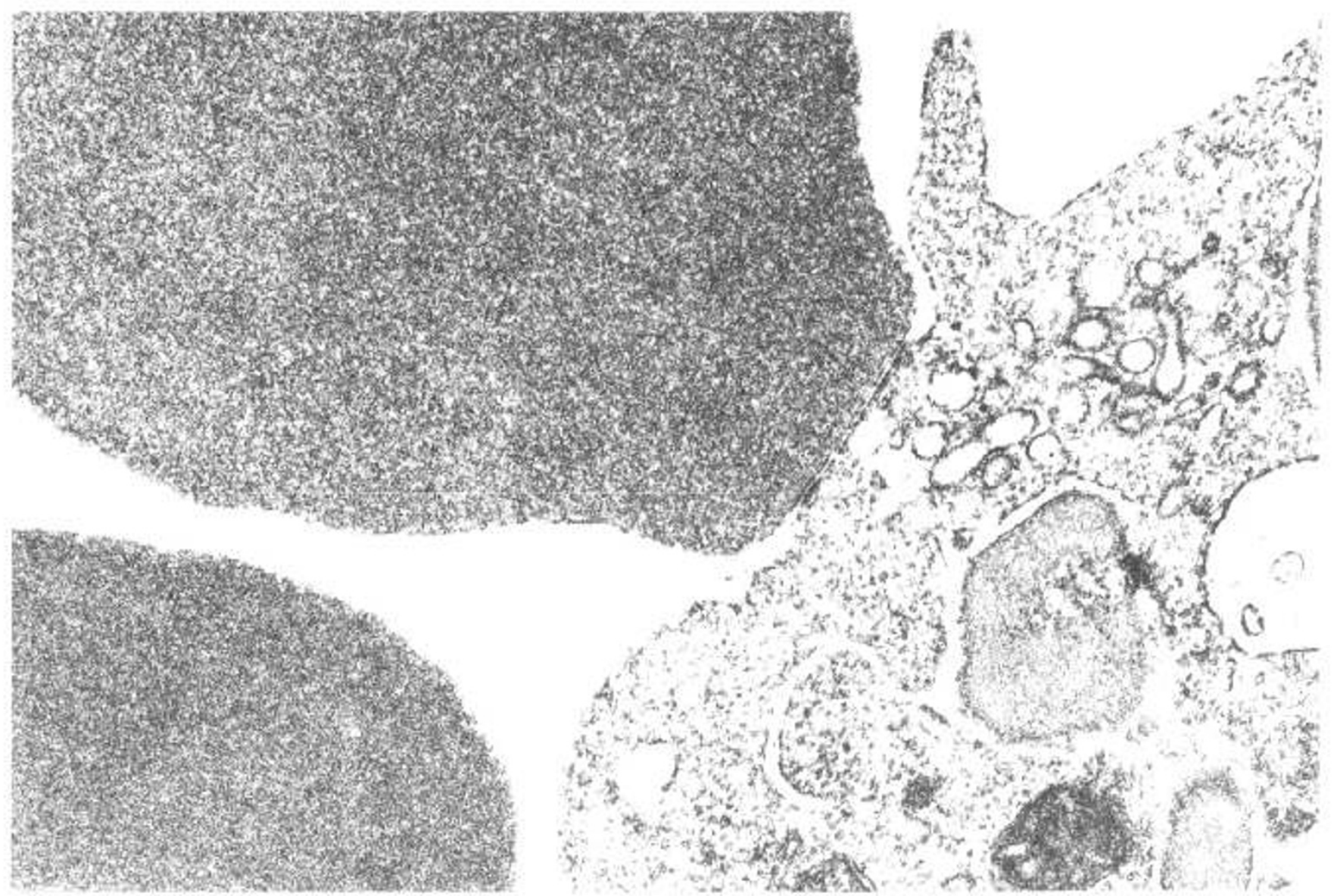

Fig. 4. Higher magnification of capped T lymphocyte showing approximation of cell Golgi vesicles to site of red cell adherence $(\times 68,450)$. Lead and uranyl acetate stain. 
by SEM indicated the possibility that at least some of the erythrocyte binding was due to other mechanisms. MFC's may be "secretors", as suggested by Duffus and Allan (8) in their observation of large RFC's; however, whether a hemagglutinin was released to cause binding of sheep red cells on outer layers is at present unknown. Haskill et al. (14) classified mouse lymphoid cell populations by their ability to bind few or many sheep red cells and found a shift of population either after animals were thymectomized or cells were treated with anti- $\theta$ serum. Multilayered RFC's seemed to be equivalent to secretory cells or plaque forming cells in their experiments. In man, however, spontaneous rosette-forming cells derived from untreated lymphocytes are exclusively $T$ cells. Nevertheless, some human B cells may be induced to reveal receptors for SRBC, as was suggested by Chapel (6) and Bentwich et al. (4) on the basis of studies utilizing cells treated with papain or neuraminidase. The numbers of RFC's we observed after papain treatment would require $B$ cell conversion to rosette formers. There was also a marked increase in the ratio of morula cells, so that it is probable that B cells also were involved in morula formation.

Of interest was the ability of SRBC's to induce cap formation after the cells were incubated at $37^{\circ}$. The process was found to be time dependent. This phenomenon was quite similar to redistribution of surface immunoglobulin molecules induced by antiimmunoglobulin antibody on B cells observed by Taylor et al. (24) and described for surface molecules of other cells as well (23). It appears that movement of membrane receptors is a basic process of cells. The role of this phenomenon in antigen processing and the initiation of immunoglobulin synthesis and secretion is unknown, but it appears to be a necessary early event (20). Whether the $S R B C$ receptor of $T$ cells is associated with or part of the surface systems which interacts with antigens is at present unknown, but further studies of its distribution and its variant, the MFC, may prove helpful in evaluating and understanding $T$ cell function.

\section{SUMMARY}

A rosette-forming $\mathrm{T}$ lymphocyte characterized by a plethora of binding sites is found in increased numbers in the thymus gland, early in ontogeny and in certain disease states. It may represent a primitive $\mathrm{T}$ lymphocyte.

\section{REFERENCES AND NOTES}

1. Ammann, A. J., and Hong, R.: Selective IgA deficiency and autoimmunity. Clin. Exp. Immunol., 7: 833 (1970).

2. Anderson, T. F.: Techniques for the preservation of three-dimensional structure in preparing specimens for the electron microscope. N. Y. Acad. Sci., 13: 130 (1951).

3. Bach, M. L., Huang, S. W., Hong, R., and Poulik, M.D.: B $_{2}$-microglobulin: Association with lymphocyte receptors. Science, $182: 1350$ (1973).

4. Bentwich, Z., Douglas, S. D., Skultelsky, E., and Kunkel, H. G.: Sheep red cell binding to human lymphocytes treated with neuraminidase; enhancement of T cell binding and identification of a subpopulation of B cells. J. Exp. Med., 137: 1532 (1973).

5. Brain, P., Gordon, J., and Willetts, W. A.: Rosette formation by peripheral lymphocytes. Clin. Exp. Immunol., 6: 681 (1970).

6. Chapel, H. M.: The effects of papain, trypsin, and phosphilipase $A$ on rosette formation. Transplantation, 15: 320 (1973).

7. Coombs, R. R. A., Gurner, B. W., Wilson, A. B., Holm, G., and Lindgren, B.: Rosette-formation between human lymphocytes and sheep red cells not involving immunoglobulin receptors. Int. Arch. Allergy, 39: 658 (1970).
8. Duffus, W. P. H., and Allan, D.: A study of the ontogeny of specific immune responsiveness amongst circulating leukocytes in the chicken. Immunology, 16 : 337 (1969).

9. Dwyer, J. M., Bullock, W. E., and Field, J. P.: Disturbance of the blood T:B lymphocyte ratio in lepromatous leprosy. N. Engl. J. Med., 288: 1036 (1973).

10. Fanger, M. W., and Bernier, G. M.: Subpopulations of human lymphocytes defined by $\mathrm{B}_{\mathbf{2}}$-microglobulin. J. Immunol., 111: 609 (1973).

11. Froland, S. S.: Binding of sheep erythrocytes to human lymphocytes: A probable marker of T lymphocytes. Scand. J. Immunol., I: 269 (1972).

12. Golub, E. M.: The distribution of brain-associated $\theta$ antigen cross-reactive with mouse in the brain of other species. J. Immunol., 109: 168 (1972).

13. Gudat, F. G., and Villiger, W.: A scanning and transmission electron microscope study of antigen-binding on rosette-forming cells. J. Exp. Med., 137: 483 (1973).

14. Haskill, J. S., Elliott, B. E., Kerbel, R., Axelrad, M. A., and Eidinger, D. Classification of thymus-derived and marrow-derived lymphocytes by demonstration of their antigen-binding characteristics. J. Exp. Med., 135: 1410 (1972).

15. Jondal, M., Holm, G., and Wigzell, H.: Surface markers on human T and B lymphocytes. J. Exp. Med., 136: 207 (1972)

16. Lay, W. H., Mendes, N. F., Bianco, C., and Nussenzweig, V.: Binding of sheep red blood cells to a large population of human lymphocytes. 230:531 (1971).

17. Lin, P. S., Cooper, A. G., and Wortis, H. H.: Scanning electron microscopy of human T-cell and B-cell rosettes. N. Engl. J. Med., 289: 548 (1973).

18. Papamichail, M., Holborrow, E. J., Keith, H. I., and Currey, H. L. F.: Subpopulations of human peripheral blood lymphocytes distinguished by combined rosette formation and membrane immunofluorescence. Lancet, ii: 64 (1972).

19. Poulik, M. D., and Bloom, A. D.: B -microglobulin production and secretion by lymphocytes in culture. J. Immunol., /10: 1430 (1973).

20. Raff, M. C., and dePetris, S.: Movement of lymphocyte surface antigens and receptors: The fluid nature of the lymphocyte plasma membrane and its immunological significance. Fed. Proc., 32: 48 (1973).

21. Ross, G. D. Rabellino, E. M. Polley, M. J., and Grey, H. M. Combined studies of complement receptor and surface immunoglobulin-bearing cells and sheep erythrocyte rosette-forming cells in normal and leukemic human lymphocytes. J. Clin. Invest., 52: 377 (1973).

22. Silveira, N. P. A., Mendes, N. F., and Tolnai, M. E. A.: Tissue localization of two populations of human lymphocytes distinguished by membrane receptors. J. Immunol., I08: 1456 (1972).

23. Sundqvist, K. G.: Redistribution of surface antigens-a general property of animal cells? Nature New Biol., 239: 147 (1972).

24. Taylor, R. B., Duffus, P. H., Raff, M. C., and dePetris, S.: Redistribution and pinocytosis of lymphocyte surface immunoglobulin molecules induced by anti-immunoglobulin antibody. Nature New Biol., 233: 225 (1971).

25. Wybran, J., Carr, M. C., and Fudenberg, H. H.: The human rosette-forming cell as a marker of a population of thymus-derived cells. J. Clin. Invest., 51: 2537 (1972).

26. Wybran, J., and Fudenberg, H. H.: Thymus-derived rosette-forming cells in various human disease states: Cancer, lymphoma, bacterial and viral infections, and other diseases. J. Clin. Invest., 52: 1026 (1973).

27. Wybran, J., and Fudenberg, H. H.: Rosette formation, a test for cellular immunity. Trans. Ass. Amer. Phys., 84: 239 (1971).

28. Wortis, H. H., Cooper, A. G., and Brown, M. D.: Inhibition of human lymphocyte rosetting by anti-T sera. Nature New Biol., 243: 109 (1973).

29. Accepted for publication September 30, 1975.

29. Grand Island Biological Co., N.Y.

30. Studies on fetal tissue were conducted in 1973 before the moratorium on fetal research. The purpose of obtaining fetal thymus tissue was primarily for transplantation into an immunodeficient patient and informed consent of the mother of the fetus was obtained.

31. A gift of Dr. Edward Golub, West Lafayette, Ind

32. A gift of Dr. Wesley Alexander, Cincinnati, Ohio.

33. Dr. S.-W. Huang is a Fellow of the Allergy Foundation of America. Present address: Department of Pediatrics, University of Maryland Hospital, Baltimore, Md. 21201

34. This is paper no. 21 from the Immunobiology Research Center.

35. This research was supported by Grants nos. (AI-11576, AM-15159, HD-07778, and IN-35M-3 from the United States Public Health Service.

36. Requests for reprints should be addressed to: S.-W. Huang, M.D., Department of Pediatrics, University of Maryland Hospital, Baltimore, Md. 21201 (USA)

37. Accepted for publication September 30, 1975 